\title{
Landowner perceptions of the value of natural forest and natural grassland in a mosaic ecosystem in southern Brazil
}

\author{
Kirsten A. Henderson ${ }^{1}$ Mateus Reis ${ }^{2}$ Carolina C. Blanco ${ }^{3}$ - Valério D. Pillar ${ }^{3}$. \\ Rodrigo C. Printes ${ }^{2} \cdot$ Chris T. Bauch $^{4} \cdot$ Madhur Anand $^{1}$
}

Received: 26 September 2014 / Accepted: 17 June 2015/Published online: 7 July 2015

(C) The Author(s) 2015. This article is published with open access at Springerlink.com

\begin{abstract}
The forest-grassland mosaics of southern Brazil have been subject to many land use and policy changes over the decades. Like many grasslands around the world, the Campos grasslands are declining with few conservation efforts underway. In contrast, forests receive much attention and many incentives. It is hypothesized that perception of land cover has the potential to shape ecosystems. Here we conduct a questionnaire to further our understanding of decision-making practices that alter landscapes (Campos grassland, Araucaria forest, agriculture and plantation) and direct land policies in the region. Our analysis reveals that plantations are significantly less desirable than the other landscape types. However, plantation land use has increased by $87 \%$ over the past few decades, as a result of industry and government incentives. The proportions of other landscape types have remained consistent over the past two decades. Restoration of native vegetation is not a
\end{abstract}

Handled by Joshua Farley, The University of Vermont, USA.

Electronic supplementary material The online version of this article (doi:10.1007/s11625-015-0319-3) contains supplementary material, which is available to authorized users.

Madhur Anand

manand@uoguelph.ca

1 School of Environmental Sciences, University of Guelph, Guelph, ON, Canada

2 Universidade Estadual do Rio Grande do Sul, São Francisco de Paula, Rio Grande do Sul, Brazil

3 Departmento de Ecologia, Universidade Federal do Rio Grande do Sul, Porto Alegre, Rio Grande do Sul, Brazil

4 Department of Applied Mathematics, University of Waterloo, Waterloo, ON, Canada priority of landowners and restoration would require a financial incentive.

Keywords Restoration - Perception - Land use change · Forest-grassland mosaic · Policy

\section{Introduction}

Deforestation has become notorious in tropical and subtropical South America due to the impact on biodiversity and the rapid rate of clearance (Laurance et al. 2001; Mähler-Júnior and Larocca 2009; Rodrigues et al. 2009). As a result, government and private programs have established numerous conservation initiatives. Pristine grasslands are also declining, yet with little in the way of conservation efforts (Bond and Parr 2010; Overbeck et al. 2007). These grasslands are sometimes erroneously considered to be degraded lands, a result of anthropogenic activities or the early successional stages of forests, while forests are perceived as more productive, pristine landscapes full of diversity (Parr et al. 2014). Likewise, land conservation in Brazil reflects a high forest bias (SoaresFilho et al. 2014).

The Campos grasslands form a mosaic with mixed forests on slopes and valleys in the east of the South Brazilian Plateau and Araucaria forest in the highlands of southern Brazil (Müller et al. 2012). The grasslands are considered the older vegetation type; however, recent wet climatic conditions have provided a favourable environment for forest development (Behling and Pillar 2007). Fire and grazing are the main disturbances that impede forest expansion (Overbeck et al. 2007; Müller et al. 2012). Other anthropogenic influences such as afforestation of grasslands with pine plantations, logging of Araucaria 
angustifolia forests and large-scale conversion of native vegetation for agricultural purposes have altered the landscape (Behling and Pillar 2007). It is estimated that $50 \%$ of the Brazilian Campos is still natural grassland in Rio Grande do Sul (Cordeiro and Hasenack 2009) and only $12-16 \%$ of the original landscape cover remains in the Atlantic Forest (Ribeiro et al. 2009).

Forest conservation takes precedence, following a history of forest degradation in the Atlantic Forest. The Araucaria forests have been extensively logged or cleared for agriculture, yielding a critical conservation status (FAO 2009). A. angustifolia is one of few indigenous gymnosperm tree species remaining in Brazil (Rizzini 1997), with important socioeconomic and ecological benefits (Auler et al. 2002). The number of non-native species plantations (pine and eucalypts) increased by $23 \%$ across Brazil from 2005 to 2010 (ABRAF 2011). In terms of overall planted forest area, native forest species formed less than $5 \%$ of planted areas, while pine and eucalypt species comprised $93 \%$ of planted forests (MMA 2013). The state of Rio Grande do Sul recorded $14.4 \%$ increase in nonnative planted forests from 2005 to 2006 (MMA 2007). Government and social movements that promote regional development through agroforestry and, more likely, development of the forestry sector are thought to be responsible for the increase in planted area (Castro et al. 2008). Policy-makers often promote afforestation of grassland to increase productivity and mitigate elevated atmospheric carbon dioxide (Bond and Parr 2010).

Meanwhile, the native Campos grasslands of Brazil have undergone extensive land transformation. In the past three decades, approximately $25 \%$ of the Brazilian Campos have been converted to agriculture or plantation forestry (Overbeck et al. 2007). In the 1990s, agricultural practices gained popularity with rice and soya crops occupying fertile soil and forest plantations composed of eucalypts and pine on poorer growing soils (Cordeiro and Hasenack 2009; Pillar et al. 2009). These grasslands represent important biodiversity sites and provide numerous ecosystem functions, in addition to supporting livestock production and the Gaucho culture (Lang 2013; Overbeck et al. 2013); however, only $0.15 \%$ is formally protected as conservation units (Develey et al. 2008).

The Brazilian Forest Code (BFC) is responsible for the conservation of native vegetation on private lands (BFC 2012; Sparovek et al. 2012). The BFC was created in 1965 and enforced by the "environmental crimes law" established in the late 1990s (Environmental Crimes Act 1998), promoting the restoration and conservation of native vegetation (Gautreau and Vélez 2011; Soares-Filho et al. 2014). In 1965, the BFC imposed regulations and penalties, in effort to regulate land use on private properties, under the notion that forest is a common good (Stickler et al.
2013). In 1981, the Brazilian National Environmental Policy Law addressed the need to restore all degraded lands (MMA 1981). It follows that the requirements for conservation of native vegetation should constitute $80 \%$ of property in the Legal Amazon (BFC 1989), $35 \%$ in the Cerrado biome (savannas) and $20 \%$ in other biomes (BFC 1965). However, agribusiness has persistently lobbied against the BFC, claiming the provisions of the bill directly impede agricultural production (Sparovek et al. 2012; Soares-Filho et al. 2014). After record high deforestation rates in 1995, predominantly as a result of agricultural sprawl, regulation changes were prompted, enforcing stricter laws on rural property land use. Revisions of the BFC in 2012 were elicited by agribusiness' condemnation of the strict conservation laws. The most significant changes to the law involve amendments to lessen the regulations on watershed protection and riparian vegetation, as well as the elimination of hilltop native vegetation protection (BFC 2012; Novaes and Souza 2013). Furthermore, under the new regulations, land that was illegally altered prior to 2008 is exonerated from restoration requirements and property size-specific regulations were included, relaxing requirements on small properties.

On the state level, the government has been promoting alternative land use practices, primarily through increased tree cover. Silvicultural activities started in the late 1980s in Uruguay, Argentina and Rio Grande do Sul in Brazil, initiating competition among the countries to attract world corporate leaders from the cellulose industry (Gautreau and Vélez 2011). As a result, landowners received massive public subsidies. The 1992 State Forest Code forbid the use of fire to maintain grasslands (RS 1992), contributing to increased silvicultural activities (Bristot 2001; Teixeira 2011). In 2004, state environmental administration implemented Environmental Zoning for Silviculture Activity (ZAS) to regulate tree farms in Campos grasslands, according to ecological vulnerabilities defined at different spatial unit scales (Gautreau and Vélez 2011). The original ZAS regulations (2006) permitted $25-50 \%$ of property to be planted with tree farms; larger properties were permitted to convert lower percentages of land to plantation. The latest version of ZAS regulations establishes a maximum percentage of plantation per mixed spatial unit (watersheds divided by landscape unit), a minimum distance between plantations and offers watershed protection. Moreover, Brazil's environmental legislation requires each plantation of exotic trees to have an environmental permit. In addition, the Low-Carbon Agriculture program provides loans to increase agriculture productivity while reducing associated carbon emissions and supporting forest restoration (Soares-Filho et al. 2014). The native Araucaria forests in Brazil have further regulations prohibiting deforestation and promoting conservation. In 1965, the Brazilian 
Government banned the harvest of native vegetation in permanent preservation areas, which includes $A$. angustifolia (BFC 1965). As of 2001, the tree has been listed as critically endangered and export of the species has been prohibited (Thomas 2013).

Although the law requires all types of native vegetation to be protected, landowners are often unaware or do not acknowledge this (Overbeck et al. 2013). Throughout the years, the BFC and other state initiatives have experienced many changes to the legal requirements for preservation of native vegetation, known as Legal Reserves (LR), in addition there have been various incentive programs and conservation initiatives, resulting in non-conformity among landowners, while making it difficult to monitor the land use transitions (Stickler et al. 2013). Non-compliance has been an issue for policy-makers, particularly in the Amazon and Atlantic Forest biomes, over the past decades (Soares-Filho et al. 2014). A significant reason for noncompliance with LR standards is the substantial cost to landowners, not only from restoration efforts, but also through foregone income from crops and cattle ranching (Sparovek et al. 2012; Stickler et al. 2013).

Human behaviour has a significant influence on land use and ecosystem stability (Innes et al. 2013). Many studies have looked at the decision-making behind conservation ecology. The scarcity hypothesis refers to conservation based on economic returns from ecosystem resources, such as timber. When a resource becomes scarce, the market value increases, providing an incentive for individuals to protect the resource (Farber et al. 2002; Satake and Rudel 2007; Barbier 2013). Alternatively, the ecosystem service hypothesis states that environmental degradation associated with native vegetation loss increases the vulnerability of the system to further degradation, which reduces the incentive to restore ecosystem structure (Satake and Rudel 2007). Moreover, individuals frequently demonstrate imitation behaviour, following the decisions of media or respected individuals in a community (Moser 2010; Bauch and Bhattacharyya 2012). Moser (2010) underlines the importance of social norms when communicating about climate change; climate change initiatives are more likely to be accepted when the views conform to those of the social group and therefore, individuals who engage in conservation initiatives are unlikely to be ostracized.

Most land use research in Brazil has focused on the rates of decline and forest area lost, particularly in the Legal Amazon, and the role of policy-makers. Few studies have been conducted in the southern region of Brazil and even less is known about the forces driving land use transformation. The South and Southeast regions of Brazil are more heavily occupied and the majority of native vegetation is on private land (Sparovek et al. 2011).
Approximately, $80 \%$ of the Atlantic Forest biome is on private property (SOS Mata Atlântica 2012); hence the importance of enhancing our knowledge of the decisionmaking practices of landowners. The decisions landowners make and the resulting land changes form complex patterns in ecosystem landscapes. The main objective of our study is to gain knowledge on individuals' preference and perception of conservation values (including sustainable use) of natural ecosystems, relative to their abundance in the region, and how this perception changes considering past and possible future landscape compositions in the forestgrassland mosaics of southern Brazil. It is hypothesized that individuals show no preference for one or the other native landscape type (Araucaria forest or Campos grassland), compared to non-native ones (agricultural land and non-native plantation). In addition, we hypothesize that decisions regarding land use and conservation are consistent with imitation and rarity-based behaviour.

\section{Methods}

\section{Study area}

The study area is located in the region of São Francisco de Paula (town: $29^{\circ} 27^{\prime} 03^{\prime \prime} \mathrm{S}, 50^{\circ} 35^{\prime} 41^{\prime \prime} \mathrm{W}$ at an altitude of $912 \mathrm{~m}$ ), in the South Brazilian plateau, northeastern Rio Grande do Sul (RS), Brazil (Planalto das Araucárias). The regional climate is described as subtropical, with moderate temperatures (annual mean $14.5^{\circ} \mathrm{C}$ ) and high annual precipitation (mean $2252 \mathrm{~mm}$ ) without a marked dry season (Silva and Anand 2011). The northeastern region of RS represents the southern limit of the Atlantic Forest distribution (Silva et al. 2009) and is characterized by forestgrassland mosaics composed of native Campos grassland and native A. angustifolia. The soil characteristics (Andosols or Umbrisols) are uniform through the forest and grassland landscape types (Silva and Anand 2011). The primary anthropogenic land uses are cattle grazing, logging practices, agriculture and tree plantations. The $300 \mathrm{~km}^{2}$ region around São Francisco de Paula is composed of $30 \%$ native Campos grassland, $25 \%$ native Araucaria forest and $45 \%$ other human land use (agriculture and/or tree plantation) (Lang 2013).

\section{Sampling and analysis of land use}

Data regarding the perception of changes and individual interactions with the natural environment were collected using a questionnaire. Thirty properties were selected using a stratified sampling technique, in which we chose to interview cattle ranchers with significant proportions of native vegetation on their land as our reference group. 
There was also an element of "snowball" sampling, where each farmer suggested the next person to survey. Figure 1 represents a site map of the properties surveyed. Each property was given a questionnaire (see Supplementary Information for full questionnaire) with ten questions concerning the past/present composition and preference for four landscape types (native Campos grassland, native Araucaria forest, agricultural land and non-native plantation), how experiences are shared with other people about land use and opinions about the importance of the conservation of native (i.e. unplanted) ecosystems. All composition values were gathered as a percentage of the landowner's property. To assure landowners understood the classification of landscapes, landowners were shown images of native Araucaria, forest-grassland mosaic and native grassland prior to answering survey questions.

Questions 1 and 2 of the questionnaire relate to the composition of each landscape type on each landowner's property and their preferred composition. Both current land composition/preference and land composition/preference from more than 10 years ago were considered to ascertain land use and perception changes in recent years.
The next set of questions aims to determine landowner decision-making practices and primary influences. With this we include changes in the landscape in a $5 \mathrm{~km}$ radius from the landowner's property to explore whether imitation behaviour is present or if the scarcity hypothesis applies.

Questions 6 and 7 relate to the land composition in the São Francisco de Paula region. The purpose of these questions is to note the feedbacks between landowners' preference and the composition of the region.

The final set of questions was devoted to gauging the interest of landowners to restore native Araucaria forest or native Campos grassland. Question 9 presents a hypothetical scenario in which landowners' properties are composed entirely of Araucaria forest or Campos grassland; landowners were then asked how much of each native vegetation they would replace with the other. In addition, the questions explore the preference of restoring one native ecosystem over the other and the financial incentive required to convert anthropogenic land uses on their property to native vegetation.

Statistical analyses were performed using descriptive statistics and non-parametric tests (Wilcoxon signed rank

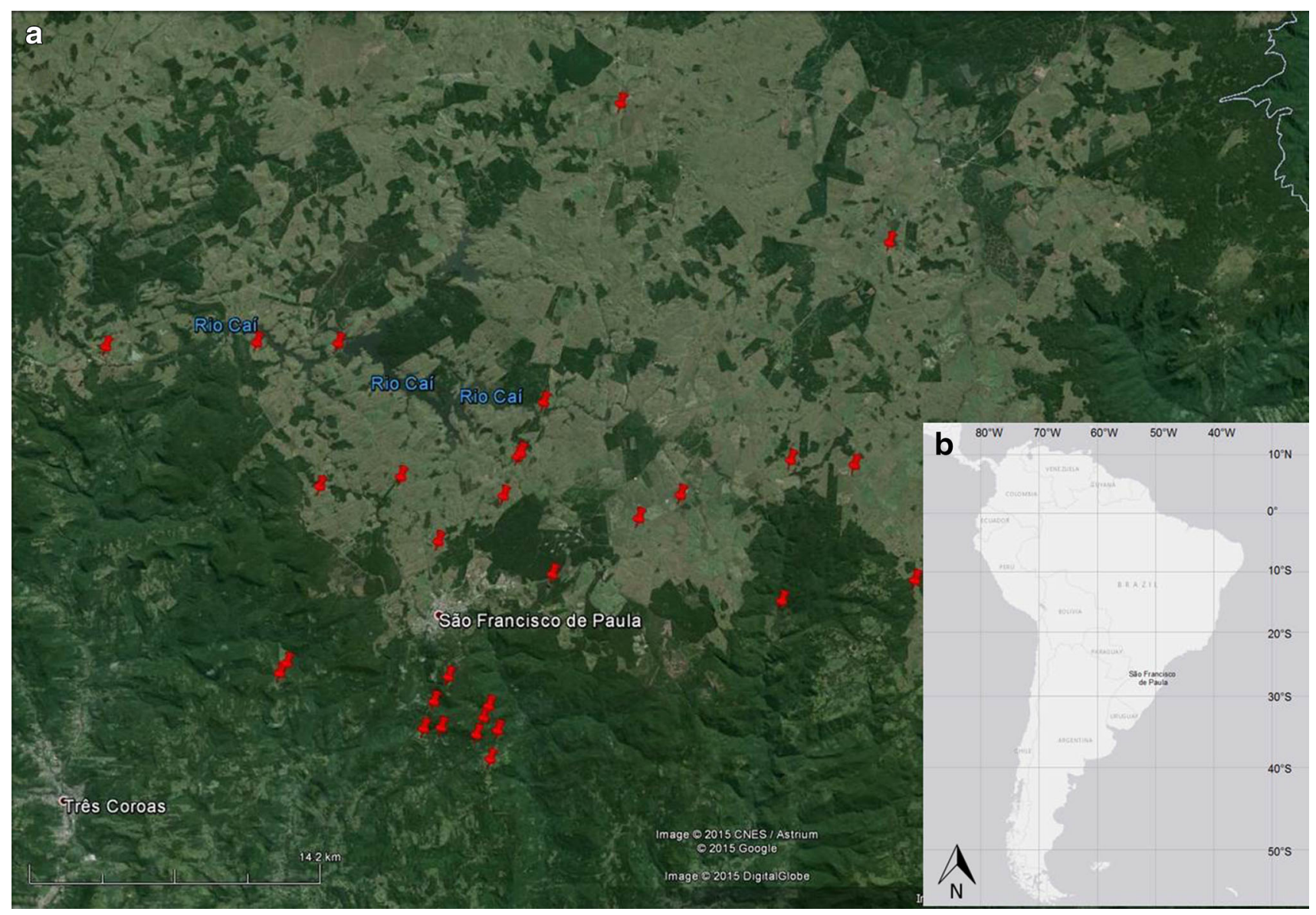

Fig. 1 Location of the study site. a Map showing the 30 properties surveyed in the São Francisco de Paula region taken from Google Earth. b Inset of South America using ArcMap (ESRI 2012) 
test, Spearman correlation) in R (R Core Team 2012). Differences were considered statistically significant when $P<0.05$.

\section{Results}

\section{Composition and Preference}

Relating to Q1, the native Araucaria forest comprises the greatest percentage of land use on surveyed properties, with an average of $35 \%$. Native Campos grassland makes up $30 \%$ of the surveyed area, giving a combined native vegetation composition of $65 \%$ with no significant difference between the amount of the two landscape types $(P=0.8642)$. The mean compositions of agriculture and non-native plantation land use are $20 \%$ and $15 \%$, respectively. There is significantly less plantation land use $(P=0.01401)$ and agriculture land $(P=0.04075)$ compared to native Araucaria forest.

The preference for each landscape type (Q2 from questionnaire) does not vary significantly compared to the current composition landscape, with the exception of preference for more agricultural land use $(P=0.01417)$. On average, the mean preference for agriculture is $35 \%$, which is $15 \%$ more agricultural land use than the current composition. The main reason landowners state for preferring agricultural land use is that agricultural practices are more profitable. The landscape composition preference for tree plantation is significantly less than the preference for both native ecosystems and agricultural land $(P<0.005)$. The landscape composition preferences for Araucaria forest, Campos grassland and agriculture do not vary significant from one another $(P>0.05)$.

\section{Composition and preference change}

In general, composition on landowner properties has not changed significantly over the past three decades (Q3a from questionnaire). There has been a greater shift towards forested land, the mean tree plantation composition increased $87 \%$, the percent composition of plantation land use on properties increased from 8 to $15 \%(P=0.01418)$, while the mean percent composition of native Araucaria forest increased from 30 to $35 \%$, a $16 \%$ increase in $A$. angustifolia composition over the years $(P=0.3244)$. The composition of Campos grassland decreased by $17 \%$, past mean compositions on individual properties decreased from 36 to $30 \%(P=0.05130)$. Likewise, the percentage of agriculture land use on individual properties decreased on average by $20 \%$ from 25 to $20 \%,(P=0.8077)$. This decrease in grassland was perceived by $83 \%$ of landowners within a $5 \mathrm{~km}$ radius of their property $(\mathrm{Q} 5$ from questionnaire). Within the $5 \mathrm{~km}$ radius surrounding their property, $52 \%$ of landowners stated they observed a shift towards increasing Araucaria forest, while $34 \%$ of landowners claim to have observed no landscape transitioning and $14 \%$ of landowners stated they observed a shift towards decreasing forest. The correlation between the composition change of both native vegetation and the observed/perceived change in the $5 \mathrm{~km}$ radius is not significant for Araucaria forest $(\rho=-0.001880, P=$ 0.9923), nor for Campos grassland $(\rho=0.1805, P=$ 0.3487). The majority of landscape changes occurred between 10 and 15 years ago.

Corresponding to $\mathrm{Q} 3 \mathrm{~b}$, landscape composition preference has not changed significantly over the years. All $P$ values for the change in composition preference are greater than 0.5 . Few individuals changed their preference for Araucaria forest composition $(n=5)$ over the past decades; however, there exists a weak negative correlation between the slight increase in preferred composition and the perceived change in forest cover within the surrounding $5 \mathrm{~km}$ radius $(\rho=-0.2602, P=0.1729)$. Three landowners changed their preferred composition of Campos grassland; the minimal decrease in individual preference change for Campos grassland shows a weak positive correlation with the perceived decrease of grassland in the surrounding area $(\rho=0.2166, P=0.2592)$. The negative correlation between the change in preferred forest composition and perceived forest cover change demonstrates rarity-based decision-making practices, inconsistent with the high discount rates on timber in Brazil (FAO 1998). The past landscape composition preference appears to be reflected in the current composition of land, which is positively correlated with the past preference for each landscape composition (Table 1).

\section{Land use influence}

The results from Q4 show that landowners are much more likely to gather information from someone they know with the same vocation ( $70 \%$ of landowners, $P=0.02932$ ), such as parents, neighbours or cooperatives. The other $30 \%$ of landowners receive information from television, the newspaper or the internet. On a scale of $1-5$, the

Table 1 Correlation between past landscape composition preference and current composition using the Spearman correlation test

\begin{tabular}{llll}
\hline Landscape type & $\rho$ & $P$ value & Strength \\
\hline Native Campos grassland & 0.7454 & 0.000002289 & Strong \\
Native Araucaria forest & 0.6159 & 0.0002908 & Strong \\
Plantation & 0.3618 & 0.0248944 & Moderate \\
Agriculture & 0.3245 & 0.08024 & Moderate \\
\hline
\end{tabular}


average self-reported influences from both personal contacts and media are 3.3 and 3.4, respectively.

\section{Regional composition}

Relating to Q6, landowners are unlikely to change their preference for Araucaria forest $(P=0.3938)$ or Campos grassland $(P=0.4313)$ after being informed of the current composition of land in the region. On average, the landowners would prefer to see the region of São Francisco de Paula composed of $39 \%$ native Campos grassland, $29 \%$ native Araucaria forest, $26 \%$ agriculture and $2 \%$ plantation (Q7 from questionnaire). The majority of landowners would prefer that non-native tree plantations be replaced by one of the three other landscape types $(P<0.00005)$ and would like to increase the income generated, in addition to the productivity of properties. Seventy-three percent $(n=22)$ of landowners stated a preference for agriculture and ranching in the region for financial reasons or food productivity. However, $17 \%$ of landowners $(n=5)$ stated the importance of landscape services provided by Araucaria forests.

The preferences for Araucaria forest and tree plantation on individual properties show weak negative correlation with the preferences in the region $(\rho=-0.04, P=0.8335$ and $\rho=-0.3187, P=0.08609$, respectively). The preference for agriculture shows a moderate positive correlation with regional preference $(\rho=0.5088, P<0.005)$ and grassland is strongly positively correlated to the regional preference $(\rho=0.6444, P<0.0005)$.

\section{Restoration}

Ninety-three percent of landowners $(n=28)$ are willing to restore Araucaria forest at the expense of Campos grassland (Q9 from questionnaire), versus an almost equal $90 \%$ ( $n=27)$ willing to restore grassland at the expense of forest $(P=1)$. Landowners consider on average transitioning $36 \%$ of hypothetical full forest cover on their property to Campos grassland, while landowners consider converting $32 \%$ of hypothetical full Campos cover to Araucaria forest $(P=0.5451)$. However, given the choice of restoring either Campos grassland or Araucaria forest on their current property (Q8 from questionnaire), the majority of landowners $(67 \%, P=0.02415)$ would rather restore Campos grassland than Araucaria forest. There is no strong negative correlation between the desire to restore the native grassland vegetation and the observed/perceived decrease in Campos grassland $(\rho=-0.09485, P=0.6245)$. Two out of 30 landowners did not select either native landscape types for restoration.
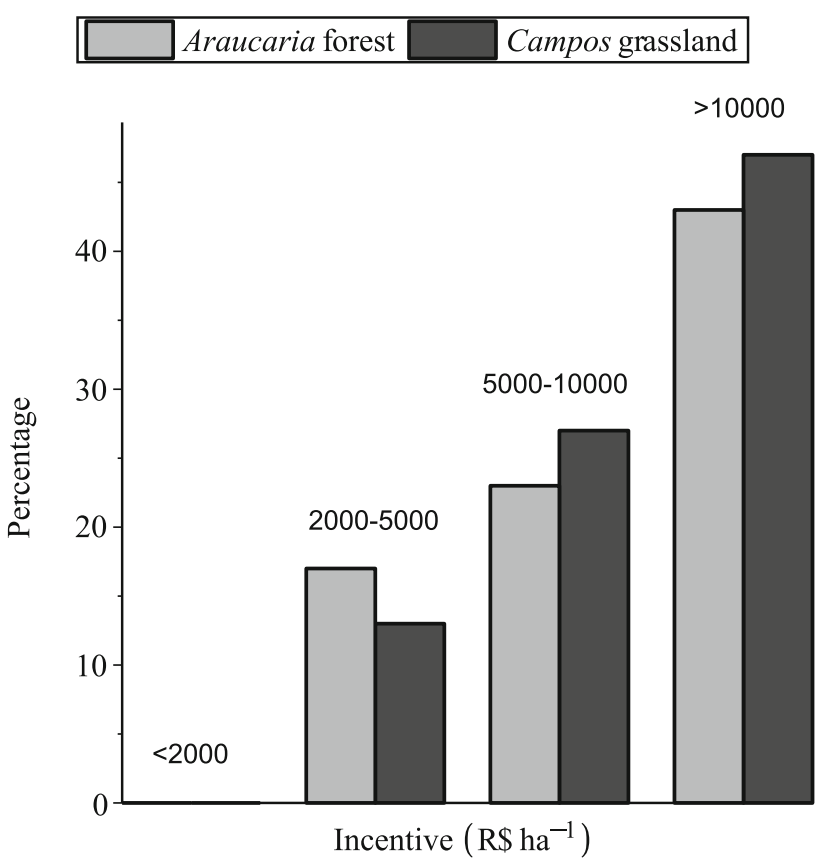

Fig. 2 Required incentive to convert cropland to native vegetation. $\mathrm{Q} 10$ asks landowners how many Reals $(\mathrm{R} \$)$ per hectare are required to consider converting cropland to native vegetation on their property. No landowners would restore native vegetation on their property without an incentive. Forty percent of landowners would restore both native vegetation landscapes for $\mathrm{R} \$ 2000$ (approx. US\$765) to $\mathrm{R} \$ 10000$ (approx. US\$3825) per hectare converted. The greatest proportion of landowners require more than $\mathrm{R} \$ 10000$ (approx. US\$3825) per hectare converted to establish native vegetation (46\% for grassland, $43 \%$ for forest). Some landowners would not restore native vegetation on their property for any amount of money (13\% for grassland, $17 \%$ for forest)

The results from Q10 show that compensation for converted croplands does not vary significantly between Araucaria forest and Campos grassland (Fig. 2).

\section{Discussion}

In past decades, restoration ecology has gained popularity in Brazil (Kageyama et al. 2003). Restoration ecology presents many challenges from environmental, social and economic perspectives. Our study offers insight into managing land use and behaviour that contribute to ecosystem transformations.

The literature indicates that landowners tend to prefer agricultural land use (Overbeck et al. 2007) and grasslands for their ability to support livestock production (Overbeck et al. 2013). Furthermore, the current value of one hectare of grassland is approximately five times greater than the same area of forest (R. Printes, personal communication). Despite the vast majority of the written comments stating a 
preference for native Campos grassland and agriculture for their ability to generate greater profits and productivity, Araucaria forest comprises the highest average composition in the region and there has been a decrease in Campos grassland over the past decades. This could be a result of the perceived benefit from forest ecosystem services or the laws that promote forest conservation and prohibit logging of the native Araucaria forest. Seventeen percent of landowners stated ecological services as a reason for maintaining forest, as well as the attraction of tourists. From landowner responses, we deduce that ecosystem services influence land management practices, in agreement with the ecosystem service hypothesis.

Forest transition in Brazil generally results from urbanization, industrialization, conservation, agricultural demand, rural exodus or land value changes (Baptista 2008). Many studies have described forest encroachment into adjacent grasslands (Asner et al. 2004; Behling and Pillar 2007; Silva and Anand 2011; Müller et al. 2012). Forest encroachment provides a well-founded explanation for the decrease in grassland and the increase in both native and exotic tree species in the region. Seed dispersal and germination are very effective at expanding over nearby grasslands (Bustamante and Simonetti 2005), especially as the climate becomes warmer and moister with increased carbon dioxide in the atmosphere. The change in legislation that prohibits the logging and export of A. angustifolia and encourages conservation appears to have slightly increased the native forest cover in the region. Furthermore, it has been suggested that fire suppression in the region is an important contributor to the expansion of forest cover (Behling and Pillar 2007).

Plantations were the only landscape type to experience a significant increase in the last 30 years. Lang (2013) noted an increase of $92.4 \%$ in plantation area, consisting mostly of Pinus sp. in the Campos de Cima da Serra region (subtropical highland grasslands, northeastern Rio Grande do Sul). We suggest that the government and private industry incentives for the cultivation of exotic species prompted an increase of silvicultural activities in the area. In addition, the forestry industry strongly influences the bans placed on fire (R. Printes, personal communication), favouring the development of plantation trees. There has been a marked increase in recent years of plantation land use, contrary to the average landowner's preference to reduce the composition of tree plantation on their property. Plantation land use is significantly less preferred than any other landscape type, possibly as a result of the high discount rates on timber in Brazil, which can make monoculture plantations economically unviable when considering production costs and profits (Oliveira et al. 1998; Soares et al. 2003).

The decrease in agricultural land use could be evidence of intensified law enforcement over the years noted by
Soares-Filho et al. (2014) or marginal growing conditions on the slopes south of São Francisco de Paula, causing landowners to abandon agriculture practices. Historically, agribusiness has taken advantage of weak enforcement and ineffective monitoring (Nepstad et al. 2014). When discussing the reasons for changing their land use, most of the landowners made changes that generated greater profits, while some landowners remarked a change in legislation that prohibited logging and certain management strategies. Grazing and fire as maintenance strategies for grasslands are not approved by the Brazilian conservation policy in protected areas (Overbeck et al. 2013), though fire use for land management is allowed on the majority of grasslands with permission from the municipal government (RS 2012). For the small percentage of grassland in protected areas, the ban on grazing and fire could contribute to the observed decrease in Campos grasslands (Oliveira and Pillar 2004).

Numerous studies have demonstrated the impact of human behaviour on landscape transitions either directly through preference for a given vegetation type and management strategies or indirectly through climate change (Bennett and Willis 2000; Asner et al. 2004; Horan et al. 2011; Innes et al. 2013). The amendments to the BFC and other conservation initiatives at the state level for Rio Grande do Sul provide some insight into the shifts in resource and ecological services perceptions over the decades. This study aims to determine what drives decision-making. The questionnaire shows that landowners are much more likely to seek information from individuals with similar experiences. The perceived change in composition within a $5 \mathrm{~km}$ radius surrounding the properties slightly influences the preference for the landscape type; however, the change in native vegetation composition on individual properties does not appear to be affected by the changes in the region. Human decision-making follows a set of valuation processes, in which individuals often select the outcome with the greatest perceived utility, the most immediate return and the greatest degree of certainty (Rangel et al. 2008; Moser 2010). Our results are consistent with decision-making practices described by Rangel et al. (2008) and Moser (2010).

From our results, it is not possible to make any conclusive remarks on the use of rarity-based decision-making practices in the region; we argue that the region has not experienced significant enough declines in native vegetation cover to generate concern that would be reflected in the questionnaire. The high discount rates in Brazil decrease gains from timber and often preclude scarcity conservation (FAO 1998; Oliveira et al. 1998). There is a significant difference in composition and preference for Araucaria forest compared with plantations $(P=0.001261)$, despite the greater profits from non-native plantations (Cubbage et al. 2007), which reflects landowner 
conservation values for native forests. The Campos grasslands are important to the gaucho culture and provide significant income to the region (Lang 2013; Overbeck et al. 2013), which is consistent with landowner comments. From landowner responses, we infer that landowners maintain land that generates the most profit while adhering to laws and regulations.

From the collected data, we gather that the preferred landscape on an individual property reflects the desired composition in the region and the information given about the region does not change the preference of landowner's composition. We argue that landowners in the region have a good understanding of the land composition in their region and thus the information given about the area had no impact on their preference because they were already aware of the regional ecosystem composition. The landscape composition of the region is similar to the average and mode compositions on individual property, which may suggest imitation behaviour.

Rates of transformation and degradation are not uniform throughout Rio Grande do Sul (Cordeiro and Hasenack 2009). The majority of southern Rio Grande do Sul falls within 80-100 \% compliance with the 2012 BFC (SoaresFilho et al. 2014). The region of our study showed an over $80 \%$ compliance with the $2012 \mathrm{BFC}$ and within this region landowners were shown to maintain between 0.8 and 3 times the required native vegetation. Similarly, our results indicate that the composition on each individual property varies widely, while $93 \%$ of landowners maintained at least $20 \%$ combined native vegetation. Considering the state of RS has a surplus of 664,000 ha of land in the Atlantic Forest biome, with the potential to be converted from native vegetation to other land uses and 3 million surplus ha of land in the Pampa biome (Soares-Filho et al. 2014), we reason that the $7 \%$ of landowners with less than $20 \%$ LR may legally be permitted to maintain a lower composition of native vegetation through the Environmental Reserve Quota; whereby, landowners can trade their excess required native vegetation quota with others, in the same biome, that failed to meet the LR (Soares-Filho et al. 2014).

One very clear pattern that emerged from the respondents is that restoration can be costly and large incentives are required by landowners to restore native vegetation at the expense of croplands. Strict regulations can result in compliance issues, as seen by increasing the LR requirement (Stickler et al. 2013). From the comments on the questionnaires it is evident that land productivity and profit are important to landowners, we argue more important than restoring native vegetation. Landowner responses concerning the amount required for restoration indicate that restoration is viewed as selling land to conservation authorities. The average cropland is valued at approximately R \$9500 (approx. US\$3625) (IFMB 2011), whereas forested land is valued at $\mathrm{R} \$ 1000$ (approx. US\$380) and grassland at R\$5000 (approx. US\$1910) (R. Printes, personal communication). Our work suggests that landowners wish to profit from restoration initiatives or reclaim lost revenue from cropland conversion. The majority of landowners would rather restore native Campos grassland on their property at the expense of croplands since grasslands inherently support ranching practices, the sole income for many of the landowners. Conversely, landowners demonstrate equal willingness to restore both native ecosystems at the expense of the other in the hypothetical situation.

\section{Conclusion}

This analysis provides useful information for policy-makers by quantifying changes in land management and preference of land use in São Francisco de Paula over the past decades. We must take into consideration that surveyed landowners maintain properties in the region with the highest composition of native vegetation and thus are likely to be in compliance with land management regulations. While the collection of landowner knowledge has some inherent bias it does not appear to include deliberate misinformation, the results are consistent with landscape changes noted in other studies of the region, as well as changes in policy (Oliveira and Pillar 2004; Overbeck et al. 2013; Soares-Filho et al. 2014). The major study results indicate that there is no preference for either of the native vegetation types, in agreement with our null hypothesis. In addition, we find that landowners have no significant preference for the proportion of landscape composed of agriculture over native vegetation, while plantations are clearly less desirable than any other landscape. From landowner written responses, we conclude that land productivity and profit are priorities for the majority of landowners. However, maintenance of ecosystem services also influences the decision-making of many landowners. Sampling of other landowners' preferences further influences individuals, while the proportion of native vegetation does not seem to be low enough to test the scarcity hypothesis. Restoration of native vegetation is not a priority of landowners and any form of restoration would require a financial incentive. Our results suggest that the economics of restoration and conservation are crucial to the success of policies and the maintenance of native ecosystems.

The responses of landowners to the questionnaire give an indication of when changes in legislation have occurred and whether or not they were successful. Landowners in the region of São Francisco de Paula show a high compliance with regulations and this in turn appears to maintain some level of conservation of the native vegetation. 
Reflecting on past land management strategies and adapting future policies to include information on landowner preferences can circumvent unsuccessful strategies and promote positive changes (Fensham and Fairfax 2003). The data collected on land composition in the region enhance our understanding of land management strategies and vegetation composition for future fire regulation policies. The results will be used in future analysis to parameterize land use behavioural models.

Acknowledgments This project was funded by the Natural Sciences and Engineering Research Council of Canada and the James S. McDonnell Complex Systems Scholar Award.

Open Access This article is distributed under the terms of the Creative Commons Attribution 4.0 International License (http://creativecommons.org/licenses/by/4.0/), which permits unrestricted use, distribution, and reproduction in any medium, provided you give appropriate credit to the original author(s) and the source, provide a link to the Creative Commons license, and indicate if changes were made.

\section{References}

ABRAF, Brazilian Association of Forest Plantation Producers (2011) ABRAF Statistical Yearbook 2011. http://research.cnr.ncsu.edu/ sofac/ABRAF_Statistical_Annual_Report_2011_English.pdf. Accessed 28 Aug 2014

Asner GP, Elmore AJ, Olander LP, Martin RE, Harris AT (2004) Grazing systems, ecosystem responses, and global change. Annu Rev Environ Resour 29:261-299

Auler NMF, Reis MS, Guerra MP, Nodari RO (2002) The genetics and conservation of Araucaria angustifolia: I. Genetic structure and diversity of natural populations by means of non-adaptive variation in the state of Santa Catarina. Brazil. Genet Mol Biol 25:329-338. doi:10.1590/S1415-47572002000300014

Baptista SR (2008) Metropolitanization and forest recovery in southern Brazil: a multiscale analysis of the Florianópolis City-Region, Santa Catarina State, 1970 to 2005. Ecol Soc 13:5. http://www. ecologyandsociety.org/vol13/iss2/art5/. Accessed 31 Jan 2015

Barbier EB (2013) Economics, natural-resource scarcity and development: conventional and alternative views. Routledge Revivals, New York

Bauch CT, Bhattacharyya S (2012) Evolutionary game theory and social learning can determine how vaccine scares unfold. PLoS Comput Biol 8:e1002452. doi:10.1371/journal.pcbi.1002452

Behling H, Pillar VD (2007) Late quaternary vegetation, biodiversity and fire dynamics on the southern Brazilian highland and their implication for conservation and management of modern Araucaria forest and grassland ecosystems. Philos Trans R Soc B 362:243-251. doi:10.1098/rstb.2006.1984

Bennett KD, Willis KJ (2000) Effect of global atmospheric carbon dioxide on glacial-interglacial vegetation change. Glob Ecol Biogeogr 9:355-361

Bond WJ, Parr CL (2010) Beyond the forest edge: ecology, diversity and conservation of the grassy biomes. Biol Conserv 143:2395-2404. doi:10.1016/j.biocon.2009.12.012

BFC, Brazil Forest Code (1989) Lei n ${ }^{\circ}$ 7.803, de 18 de julho de 1989. Presidência da República. Casa Civil. Subchefia para Assuntos Jurídicos, Brasília
Brazil Forest Code (BFC) (1965) Lei n ${ }^{\circ} 4.771$, de 15 de setembro de 1965. Presidência da República. Casa Civil. Subchefia para Assuntos Jurídicos, Brasília

Brazil Forest Code (BFC) (2012) Lei ${ }^{\circ}$ 12.727, de 25 de maio de 2012. Presidência da República. Casa Civil. Subchefia para Assuntos Jurídicos, Brasília

Bristot A (2001) Planalto das Araucárias-um ecossistema em perigo de extição? Agroecol Desenv Rur Sustent 2:24-31

Bustamante RO, Simonetti JA (2005) Is Pinus radiate invading the native vegetation in central Chile? Demographic responses in a fragmented forest. Biol Invasions 7:243-249

Castro AWV, Pedrozo EA, Quadros JL (2008) Cadeias produtivas do agronegócio florestral na região Sul do Brasil. III Encontro CEPAN: Vantagens Competitivas dos Agronegócios no Mercosul, Porto Alegre. http://cdn.fee.tche.br/jornadas/2/E13-06.pdf. Accessed 29 June 2015

Cordeiro JLP, Hasenack H (2009) Cobertura vegetal atual do Rio Grande do Sul. In: Pillar VD et al (eds) Campos Sulinos: Conservação e Uso Sustentável da Biodiversidade. Ministéro do Meio Ambiente, Brasília, pp 285-299

Cubbage F, Rubilar R, Siry J, Mac Donagh P, Báez MN, Sawinski J Jr, Ferreira A, Hoeflich V, Olmos VM, Ferreira G, Balmelli G, Alvarez J, Donoso P (2007) Timber investments returns for plantations and native forests in South America and the Southern United States. New For 33:237-255. doi:10.1007/s11056-0069025-4

Develey PF, Setubal RB, Dias RA, Bencke GA (2008) Conservação das aves e da biodiversidade no bioma Pampa aliada a sistemas de produção animal. Rev Bras Ornitol 16:308-315

Environmental Crimes Act (1998). Lei $\mathrm{n}^{\circ}$ 9.605, de 12 de fevereiro de 98. Presidência da República. Casa Civil. Subchefia para Assuntos Jurídicos, Brasília

Environmental Systems Resource Institute (ESRI) (2012) ArcMap 9.2. ESRI, Redlands

Farber SC, Costanza R, Wilson MA (2002) Economic and ecological concepts for valuing ecosystem services. Ecol Econ 41:375-392. doi:10.1016/S0921-8009(02)00088-5

Fensham RJ, Fairfax RJ (2003) A land management history for central Queensland, Australia as determined from landholder questionnaire and aerial photography. J Environ Manag 68:409-420. doi:10.1016/S0301-4797(03)00110-5

Food and Agriculture Organization of the United Nations (FAO) (1998) Estimating timber depreciation in the Brazilian Amazon. http://www.fao.org/docrep/005/ab601e/ab601e06.htm. Accessed 28 April 2015

Food and Agriculture Organization of the United Nations (FAO) (2009) Adapting to climate change. http://www.fao.org/docrep/ 011/i0670e/i0670e07.htm. Accessed 31 Jan 2015

Gautreau P, Vélez E (2011) Strategies of environmental knowledge production facing land use changes: insights from the Silvicultural Zoning Plan conflict in the Brazilian state of Rio Grande do Sul. Cybergeo Eur J Geogr. http://cybergeo.revues.org/24881. Accessed 20 May 2014

Horan RD, Fenichel EP, Drury KLS, Lodge DM (2011) Managing ecological thresholds in coupled environmental-human systems. Proc Natl Acad Sci USA 108:7333-7338. doi:10.1073/pnas. 1005431108

Innes C, Anand M, Bauch CT (2013) The impact of humanenvironment interactions on the stability of forest-grassland mosaic ecosystems. Sci Rep 3:2689. doi:10.1038/srep02689

International Farmland Market Bulletin (IFMB) (2011) An overview of international values. http://www.investag.co.uk/Bulletin2011. pdf. Accessed 23 Sept 2014

Kageyama PY, Gandara FB, Oliveira RE (2003) Biodiversidade e restauração da floresta tropical. In: Kageyama PY et al (eds) 
Restauração Ecológica de Ecossistemas Naturais. FEPAF, Botucatu, pp 27-48

Lang M (2013) Change of land use and land cover by silvicultural expansion on the Campos de Cima da Serra, Rio Grande do Sul, Brazil (2002/03-2008/09). M.Sc. Thesis, Technische Universität München, Germany

Laurance WF, Albernaz AKM, Da Costa C (2001) Is deforestation accelerating in the Brazilian Amazon. Environ Conserv 28:305-311. doi:10.1017/S0376892901000339

Mähler-Júnior JKF, Larocca JF (2009) Fitofisionomias, desmatamento e fragmentação da Floresta com Araucária. In: Fonseca CR, Souza AF, Leal-Zanchet AM, Dutra TL, Backes A, Ganade G (eds) Floresta com Araucária: Ecologia, Conservação e Desenvolvimento Sustentável. Holos, Ribeirão Preto

Ministério do Meio Ambiente (MMA) (1981) Lei n 6.938, de 31 de agosto de 1981. Dispõe sobre a Política Nacional do Meio Ambiente, seus fins e mecanismos de formulação e aplicação, e dá outras providências. Brasília. Diário Oficial da República Federativa do Brasil, Brasília (1981 set. 02)

Ministério do Meio Ambiente (MMA) (2007) Evolução da área com floresta plantada. http://www.mma.gov.br. Accessed 4 July 2014

Ministério do Meio Ambiente (MMA) (2013) Florestas do Brasil em resumo dados de 2007-2012. http://www.mma.gov.br. Accessed 20 Jan 2015

Ministério Público Estado do Rio Grande do Sul (RS) (1992) Lei Estadual $\mathrm{n}^{\circ} 9.519$ de 21 janeiro de 1992. Institui o Código Florestal do Estado do Rio Grande do Sul e dá outras providencias

Ministério Público Estado do Rio Grande do Sul (RS) (2012) Lei Estadual $\mathrm{n}^{\circ} 13.931$ de 30 janeiro de 2012. Institui o Código Florestal do Estado do Rio Grande do Sul e dá outras providencias

Moser SC (2010) Communicating climate change: history, challenges, process and future directions. Wires Clim Change 1:31-53. doi:10.1002/wcc.011

Müller SC, Overbeck, Blanco CC, Oliveira JM, Pillar VD (2012) South Brazilian forest-grassland ecotones: dynamics affected by climate, disturbance and woody species traits. In: Myster RW (ed) Ecotones between forest and grassland. Springer, New York. doi:10.1007/978-1-4614-3797-0_7

Nepstad DC, McGrath D, Stickler C, Alencar A, Azevedo A, Swette B, Bezerra T, DiGiano M, Shinada J, Motta RS, Armijo E, Catello L, Branso P, Hansen MC, McGrath-Horn M, Oswaldo C, Hess L (2014) Slowing Amazon deforestation through public policy and interventions in beef and soy supply chains. Science 344:1118-1123. doi:10.1126/science. 1248515

Novaes RLM, Souza RF (2013) Legalizing environmental exploitation in Brazil: the retreat of public policies for biodiversity protection. Trop Conserv Sci 6:477-483

Oliveira JM, Pillar VD (2004) Vegetation dynamics on mosaics of Campos and Araucaria forest between 1974 and 1999 in Southern Brazil. Community Ecol 5:197-202

Oliveira AD, Leite AP, Botelho SA, Scolforo JRS (1998) Avaliação econômica da vegetação de cerrado submetida a diferentes regimes de manejo e de povoamentos de eucalipto plantado em monocultivo. Revista Cerne 4:34-56

Overbeck GE, Müller SC, Fidelis A, Pfadenhauer J, Pillar VD, Blanco CC, Boldrini II, Both R, Forneck ED (2007) Brazil's neglected biome: the South Brazilian Campos. Perspect Plant Ecol 9:101-116. doi:10.1016/j.ppees.2007.07.005

Overbeck GE, Hermann J, Andrade BO, Boldrini II, Kiehl K, Kirmer A, Koch C, Kollmann J, Meyer ST, Müller SC, Nabinger C, Pilger GE, Trindade JPP, Vélez-Martin E, Walker EA, Zimmermann DG, Pillar VD (2013) Restoration ecology in Brazil-time to step out of the forest. Nat Conserv 11:92-95. doi:10.4322/ natcon.2013.015
Parr CL, Lehmann CER, Bond WJ, Hoffmann WA, Andersen AN (2014) Tropical grassy biomes: misunderstood, neglected, and under threat. Trends Ecol Evol 29:205-213. doi:10.1016/j.tree. 2014.02.004

Pillar V, Müller SC, de Souza Castilhos ZM, Avila Jacques AV (eds) (2009) Campos Sulinos. Conservação e uso sustentável da biodiversidade, Brasília, Ministério de Meio Ambiente, Secretaria de Biodiversidade e Florestas, Departamento de Conservação da Biodiversidade

R Core Team (2012) R: a language and environment for statistical computing. R Foundation for Statistical Computing, Vienna

Rangel A, Camerer C, Montague PR (2008) A framework for studying the neurobiology of the value-based decision making. Nat Rev Neurosci 9:545-556. doi:10.1038/nrn2357

Ribeiro MC, Metzger JP, Martensen AC, Ponzoni FJ, Hirota MM (2009) The Brazilian Atlantic Forest: how much is left, and how is the remaining forest distributed? Implications for conservation. Biol Conserv 142:1141-1153. doi:10.1016/j.biocon. 2009. 02.021

Rizzini CT (1997) Tratado de fitogeografia do Brasil, 2nd edn. Ambito Cultural Edicoes, Rio de Janeiro

Rodrigues RR, Lima RAF, Gandolfi S, Nave AG (2009) On the restoration of high diversity forests: 30 years of experience in the Brazilian Atlantic Forest. Biol Conserv 142:1242-1251. doi:10.1016/j.biocon.2008.12.008

Satake A, Rudel TK (2007) Modeling the forest transition: forest scarcity and ecosystem service hypotheses. Ecol Appl 17:2024-2036

Silva LCR, Anand M (2011) Mechanisms of Araucaria (Atlantic) forest expansion into southern Brazilian grasslands. Ecosystems 14:1354-1371. doi:10.1007/s10021-011-9486-y

Silva LCR, Anand M, Oliveira JL, Pillar VD (2009) Past century changes in Araucaria angustifolia (Bertol.) Kuntze water use efficiency and growth in forest and grassland ecosystems of southern Brazil: implications for forest expansion. Glob Change Biol 15:2387-2396. doi:10.1111/j.1365-2486.2009.01859.x

Soares TS, Carvalho RMMA, do Vale AB (2003) Avaliação econômica de um povoamento de Eucalyptys grandis destinado a multiproductos. Resvista Árvore 27:689-694. doi:10.1590/ S0100-67622003000500011

Soares-Filho B, Rajão R, Macedo M, Carneiro A, Costa W, Coe M, Rodrigues H, Alencar A (2014) Cracking Brazil's forest code. Science 344:363-364. doi:10.1126/science.1246663

Sparovek G, Barretto A, Klug I, Papp L, Lino J (2011) A revisão do Código Florestral Brasileiro. Novos Estudos 89:111-135

Sparovek G, Berndes G, Baretto AGOP, Klug ILF (2012) The revision of the Brazilian Forest Act: increased deforestation or a historic step towards balancing agricultural development and nature conservation? Environ Sci Policy 16:65-72. doi:10.1016/ j.envsci.2011.10.008

SOS Mata Atlântica (2012) Unindo esforços pela conservação em terras privadas. http://www.sosma.org.br/blog/unindo-esforcospela-conservacao-em-terras-privadas/. Accessed 9 April 2015

Stickler CM, Nepstad DC, Azevedo AA, Mcgrath DG (2013) Defending public interests in private lands: compliance, costs and potential environmental consequences of the Brazilian Forest Code in Mato Grosso. Philos Trans R Soc B 368:20120160. doi:10.1098/rstb.2012.0160

Teixeira BM (2011) Proibição da Queima de Campo, Solução ou Problema? Impactos Socioeconômocos, socioculturais e ambientais no município de São Francisco de Paula, RS. Thesis, Universidade Federal do Rio Grande do Sul

Thomas P (2013) Araucaria angustifolia. The IUCN Red List of Threatened Species. Version 2014.1. http://www.iucnredlist.org. Accessed 7 July 2014 